\title{
Global Law Firms in Real-World Contexts: Practical Limitations and Ethical Implications
}

\author{
Eve Darian-Smith \\ Global Studies Department, University of California, Santa Barbara, USA \\ Email: darian@global.ucsb.edu
}

Received 19 February 2015; accepted 15 March 2015; published 18 March 2015

Copyright (C) 2015 by author and Scientific Research Publishing Inc.

This work is licensed under the Creative Commons Attribution International License (CC BY).

http://creativecommons.org/licenses/by/4.0/

(c) (i) Open Access

\begin{abstract}
This article argues that despite the rise in the numbers of global law firms in recent years, the future of these firms should not be assumed given escalating levels of economic (and legal) uncertainty. These uncertainties are the result, in part, of growing global and regional conflicts, terrorism, environmental degradation, pandemics, forced migrations, trade embargoes and so on which are in turn linked to global inequalities and disparities of wealth between and within the global south and global north. It is argued that global law firms, as the "lubricators of global capitalism", should pay attention to the localized real-world impacts of finance, development and trade that their legal work enables. This is important not only to ensure the future security and revenues of global law firms, but more importantly to ensure democratic aspirations and the stability of democratic institutions around the world.
\end{abstract}

\section{Keywords}

Global Law Firms, Globalization, Neoliberalism, Democracy, Social Resistance, Global Inequality

\section{Introduction}

Despite many years of economic recession, global law firms have risen in numbers and have profited enormously with emerging economies, expanding markets, booming extraction industries and highly lucrative digital technologies. Leading law schools compete to have their graduates find employment in these firms which are considered a significant measure of the institution's success and prestige. Global law firms represent the pinnacle of legal practice for many in the corporate world, offering a tantalizing arena of sky-high salaries, international travel, and a Fortune Global 500 clientele. 
Notwithstanding global law firms' enormous financial success to date, the question posed in this article is whether these firms can sustain their profits in the long run given the escalating complexities and tensions of our current world order and specifically the escalating vulnerabilities of global capitalism. This may seem a strange question given that the leading global law firms are making \$ billions in annual revenues. However, measuring success only in terms of profit overlooks escalating inequalities amongst ordinary people living in the places in which many trade and finance investments are implemented. And it is these very inequalities that are helping to make global corporate transactions more risky, profits less certain, and bring the future of elite law firms that service "big business" into question. One only has to think of the fluctuating price of oil in early 2015 — due to a range of regional and global conflicts that include trade sanctions against Russia, ongoing regional wars in the Ukraine and Syria, and the terrorist activities of ISIS - to appreciate the vulnerabilities of global capitalism. Climate change, escalating global environmental degradation, food insecurity, pandemics, forced migrations of people and the rise of global inequalities are all factors contributing to profound levels of economic (and legal) uncertainty.

Against a backdrop of unpredictable real-world contexts, thinking about the future of the global law firm and its role in a global political economy raises a number of issues explored in this article. First, will the claim of global law firms - that they service the needs of global markets operating in a de-territorialized stratosphere above the melee of local political and cultural tensions-be so easy to sustain in the coming decades? Second, and related to the first, given increasing levels of insecurity across nations, regions and continents how long will global law firms be able to maintain their huge margins of profit? More profoundly, as the "lubricators of global capitalism” (Faulconbridge et al., 2008: p. 455), are global law firms inadvertently involved in economic processes that promote social inequality and ultimately undermine the principles of democracy as well as the enduring legitimacy and authority of national and global legal institutions? If this is the case, then how may our thinking about the value of global law firms change in light of these unforeseen consequences and negative impacts? In short, what may the future hold for global law firms in the coming decades of the $21^{\text {st }}$ century?

\section{The Rise of the Global Law Firm}

The rise of the global law firm in the 1990s happened very quickly, as noted by Tony Angel, former managing partner at Linklaters, one of the world's mega law firms (Angel, 2007: p. 198). In this period conventional law firms were forced to adapt to keep pace with new technologies, deregulation of tariff barriers, and "rapidly integrating world markets" that transformed industrial production through the "transfer of manufacturing to new and rapidly developing low cost centers" (Angel, 2007: p. 199). While not spelt out in this rather sanitized historical account, what happened was that western manufacturing took advantage of a deregulated free-market economy and moved industrial plants to the third world to exploit pools of cheap labor and raw materials. To keep their competitive advantage, law firms had to adapt their business model to provide legal services for transnational corporations in this changing global economy. Law firm strategies included opening up foreign offices as well as merging with overseas firms in an effort to harmonize laws across national jurisdictions and "offer seamless legal service throughout their multi-office base” (Le Goff, 2007: p. 138).

What constitutes a global law firm is not entirely clear. As noted by William Twining, a global law firm "can mean one that offers services relating to all systems of law generally, or only in respect of some particularly transnational (typically commercial or financial) fields. In this context, "global” may refer to the client base, location of offices, types of specialized services offered, or just the larger law firms in the world (however they are geographically distributed) in terms of numbers of lawyers or numbers of countries in which they have law offices” (Twining, 2009: p. 23). However, as Twining continues, the primary criteria for eligibility as one of the world's largest law firms is typically how much annual revenue a firm makes. Despite an economic recession, in 2012 the gross revenue for the world's top 100 global law firms grew by 3.8 percent to a record high of $\$ 85$ billion. Moreover, these global law firms are almost exclusively situated in the global north. In 2013, 77 of the world's top-grossing firms were American and 13 were British. The year's list also included five Australian firms and one firm each from Canada, China, France, Spain, and the Netherlands (Zaretsky, 2013).

The numbers of global law firms have risen dramatically since the 1980s (Sokol, 2007; Faulconbridge et al., 2008). These law firms have played a major role in creating a global finance and business sector capable of facilitating transnational corporatism across nations, regions and continents. Global law firms are "called on to participate in complex transactions helping businesses tap into sources of finance for investment” (Flood, 2007: p. 35). 
And to this end, global law firms provide a number of services that are designed to facilitate international transactions eager to capitalize on "low labor costs and cheap raw materials" (Flood, 2007: p. 35). Depending upon one's needs, global law firms can provide legal expertise on a range of areas but are most commonly associated with foreign investment, international banking, tax planning and commercial trade. Global law firms enable Chinese lawyers to connect to French, English and Saudi Arabian lawyers in navigating an elite world of global finance and commercial ventures. They are, in short, viewed as an essential component in facilitating communication across legal systems and legal cultures, providing commercial legal consultants who engage with likeminded business partners around the world. Global law firms have become essential "lubricators of global capitalism" (Faulconbridge et al., 2008: p. 455).

Global law firms affirm a dominant neoliberal economic thinking that presupposes a unified value system (i.e. free-market capitalism) that is common to all legal players. Global law firms promote the narrative that law is applicable across a range of corporate boardrooms and commercial headquarters. Global law practitioners, through the contracts that they draft and the legal negotiations that they shepherd, function at an abstract level seemingly distant from the places and people that their negotiations impact. So while numerous countries such as Brazil and China bar foreign lawyers from advising on local law, this is not seen as a significant impediment to business given that lawyers can still practice US and international law which govern the majority of global finance and corporate transactions. Moreover, many global law firms have merged with national firms in these economically lucrative jurisdictions whose locally licensed practitioners can provide domestic services if needed (Silver, 2007). In overcoming the constraints and accountability of national legal cultures, global law firms present a top-down, market-framed, harmonized legal worldview that seeks to ignore the complex contexts in which commercial ventures must operate and—figuratively and literally—come to ground.

In addition to masking their local impacts, international corporate law firms "sanctify the relationships that global actors form when they engage in business” (Flood, 2007: p. 38). Global law firms provide a veneer of respectability as well as providing predictability, risk management, and legal consensus for the purposes of pursuing profit. The profile of respectability is not always deserved given that global law firms are well positioned to take advantage of largely unregulated transnational market operations that enjoy immunity from public accountability and continue to lack internal regulatory controls (see Howson, 2009; Harris, 2013). Lack of accountability enables deals to be struck that serve the economic self-interests of company stakeholders and investors while downplaying the possible negative local impacts and social, cultural and political consequences that may result from finance transactions and development projects. As Royston Greenwood has noted, structural changes within law firms in the $21^{\text {st }}$ century are redefining legal practice as a "business", in turn influencing professional behavior and ethics toward chasing commercial profit and away from earlier concepts of partnership and "stewardship" (Greenwood, 2007).

There are numerous examples of huge global law firms servicing the rising numbers of transnational corporations and international economic agencies. DLA Piper, for instance, is one of the most well-known AngloAmerican firms to form in 2005 and has approximately 4,000 lawyers situated in offices in the Americas, Middle East, Europe and the Middle East. Baker \& McKenzie is another firm that has long been a leader in providing global legal services, and is regularly ranked the top global law firm in terms of revenue, lawyer count and global reach. Baker \& McKenzie employs 11,500 staff including over 4000 lawyers in 47 countries around the world $^{1}$. A relatively recent firm to join these elite rankings is the highly successful global law firm King \& Wood Mallesons. On $1^{\text {st }}$ November, 2013, King \& Wood Mallesons combined with SJ Berwin to establish what is claimed as the first global law firm headquartered in Asia'. "We are creating the global law firm for the future”, declared Co-Deputy Chairman Stephen Minns ${ }^{3}$. The King \& Wood Mallesons network now joins the top 25 largest global law firms in the world with over a $\$ 1$ billion in annual revenue. Combining the expertise of 2,700 lawyers in 30 locations across the world, the new mega-firm seeks to serve its clients across Asia, Europe, Australia and the Middle East. As graphically visualized in its global advertising campaign in which a Chinese legal textbook is stacked on top of a French civil code legal textbook ${ }^{4}$, the firm claims it bridges national legal

\footnotetext{
${ }^{1}$ http://www.ranker.com/list/100-largest-law-firms-in-the-world/business-and-company-info?page=2; accessed 1 January 2015.

${ }^{2}$ Interestingly, the firm of King \& Wood is a large Chinese law firm whose name refers to two Chinese characters that sound like King and Wood when spoken and specifically chosen to appeal to Euro/American clients (see Terry, 2008: p. 540).

${ }^{3}$ http://www.kingandwood.com/news.aspx?id=KING-WOOD-MALLESONS-AND-SJ-BERWIN-CONFIRM-COMMENCEMENT-OF-TH E-FIRST-GLOBAL-LAW-FIRM-HEADQUARTERED-IN-ASIA\&language=en

${ }^{4}$ http://www.kwm.com/slider/ad-campaigns/; accessed 1 January 2015.
} 
jurisdictions to create a new global legal platform necessary for effective commercial enterprise. That the image of neatly stacked legal systems does not correlate to today's complex global system of legal hybridization and pluralism, or the interplay between formal/informal law in transnational commercial transactions ${ }^{5}$, is glossed over in the firm's marketing campaign.

While each global law firm may reflect different managerial strategies and profiles, they are all similar in that they are constantly adapting to meet the demands of global/transnational corporatism and emerging markets. Not surprisingly, servicing Asia, and in particular India and China, has become a central concern for global law firms who claim to provide a standardized platform for the harmonization of legal transactions across very different cultural and political contexts.

\section{Law across a Global/Local Continuum-Connecting the Dots}

Despite the marketing by global law firms, the realities of how law functions in our complex interconnected world belies the claim that global legal practitioners operate in a rarified corporate realm far from the lived experiences of ordinary people. As sociolegal scholars and practitioners are increasingly acknowledging, law functions across a global/local continuum that crosses jurisdictions and a variety of emerging legal spaces (Tamanaha et al., 2012). According to Saskia Sassen, we are currently witnessing new assemblages of territory, authority, rights and power and the creation of "diverse jurisdictional geographies" that unsettle national/international conventions (Sassen, 2008; Darian-Smith, 2013). This means that international law and global finance do not operate at some higher de-territorialized level, but have various impacts at regional, national, and local levels and are in turn informed by localized responses to international norms. In short, the local is connected to the global and vice versa. Acknowledging these interconnections profoundly undermines any narrative that posits the international and global as operating "beyond" the nation-state (Darian-Smith, 2014).

Law's operating in real-world contexts across a global/local continuum is apparent all around us. For instance, on 30 July 2014, the headlines of the New York Times presented two stories side-by-side. One article detailed the increasingly tough economic sanctions being imposed by the European Union and the United States on Russia in an attempt to quell conflict in Ukraine. The other article detailed the soaring profits made by Mr. Cohen, a hedge fund operator who despite being charged with insider trading and paying a penalty of $\$ 1.2$ billion continues to make many more billions in annual profit. These two stories seem incongruous in their juxtaposition. The first involves numerous countries, regional trade agreements, proxy conflict and echoes of Cold War bilateralism. The second story inadvertently praises the greed and unethical behavior of a single American who continues to manipulate a broken financial regulatory system that has remained virtually unchanged since the global economic recession of 2008. Perhaps not surprisingly, both stories involve the consultation of global law firms experienced in global trade and finance.

Most people reading the news, and probably most legal practitioners, would see these two stories as largely unrelated. However as David Held has noted, global conflict and global finance do not operate in two parallel universes. Countries engaged in regional conflict and solo entrepreneurs gambling in global finance are different facets of an integrated global system. Both news stories inform what Held calls a world of "overlapping communities of fate" (Held, 2002: p. 57). Hence it can be argued that the two stories represent different facets of the global political economy. As Naomi Klein and others have argued, capitalism is opportunistic in taking advantage of conflict and disasters, selling guns to guerillas, nurturing deals with authoritarian governments, and making enormous profits in private security operations. But local conflicts and disasters also provide cover for a range of activities not so obviously related to war such as establishing new mining and development projects, building dams and pipelines, redirecting water resources, imposing genetically modified seeds on farmers, dumping toxins and so on (Klein, 2008, 2014).

Given the interconnections between conflicts, disasters and finances, it is shortsighted (if not disingenuous) for global legal practitioners to claim that they operate independently from local contexts and that their legal work does not have potentially negative consequences. As discussed above, the perspective of most global law firms is to disavow the messy realities of transnational legal practices that necessarily involve social, cultural, political and environmental dimensions. But while this disavowal may have held in the past, we are approaching, I would suggest, a tipping point in terms of being able to sustain this narrative beyond corporate boardrooms and elite golf courses. Today's realities of rising poverty and social inequality—in both the global south and global

5ee Merry, 2008; Michaels, 2009; Berman, 2012; Zumbansen, 2012, 2013; Twining, 2009; Tamanaha et al., 2012; Griffiths, 2013. 
north—are fermenting a new moment of global discontent. And this discontent does impact global law firms' sustainable business strategies. To put this differently, global law firms are undercutting their own long-term financial objectives by failing to adequately engage with the realities of a global economy that is deeply integrated in complex power realignments and growing resistance to the "'new normal' ideology of neo-liberal globalization" (Arthurs, 2009: p. 633). For global law firms to continue to claim that they are somehow immune from and operate independently of local politics and social conflicts is simply duplicitous.

Similarly duplicitous is the claim that global law firms are intrinsically ethical and respectable legal actors (Etherington \& Lee, 2007). As facilitators of global capital and financial investments, global legal practitioners are often involved in negotiations that reduce a company's social obligations and ensure limited liability in the event of adverse impacts (see Lothian, 2014). We should never forget, for instance, the toxic contamination of the Amazonian rainforest by Chevron's crude oil drilling and the company's failure to pay the $\$ 18$ billion judgment against it by an Ecuadorian court ${ }^{6}$. According to Amazon Watch:

Due to Chevron's toxic contamination of their soil, rivers and streams, and groundwater, local indigenous and campesino communities continue to suffer an epidemic of cancer, birth defects, miscarriages, and other ailments. Chevron has never carried out a meaningful cleanup of the mess it is responsible for, and its infrastructure continues to poison the communities of the Ecuadorian Amazon. Today, more than 30,000 Ecuadorians are fighting for justice with an international campaign and a landmark class action lawsuit in Ecuadorian courts. Despite Chevron's repeated efforts to sabotage the trial, the local people remain determined to hold Chevron accountable, demanding clean-up costs and compensation for the devastation the company caused (Amazon Watch, 2014).

Global law firms present an ethical contradiction in that they operate as "lubricators of global capitalism" while concurrently facilitating, particularly in the context of mining and energy extraction industries, unimaginable and unaccountable damage to peoples and environments (Nixon, 2011). Polluting the world's natural resources such as the Amazonian rainforest is one such consequence that everyone, including global law practitioners and their children, will have to come to terms with at some point in the future (see Klein, 2014). In a related way, human rights violations are increasingly connected to the investment lending activities of multilateral development banks (MDBs) including the World Bank and Asian Development Bank. These lending institutions are harshly criticized for their connection to human rights violations around the world (Darrow, 2006; Ghazi, 2006). The horrors of the Bangladesh Rana Plaza factory collapse in 2013 resulting in the deaths of 1,129 garment workers is emblematic of multinational corporations' legal violations of local building permits and fire codes, and the work of global legal practitioners to ensure that these very companies are not fined or suffer great financial loss. Again, while it can be argued that global law firms are not directly responsible for human rights violations it is hard to deny that many of their activities underwrite the contexts in which violations occur, as well as the legal immunities that prevent redress and compensation to the local communities harmed.

Related to issues of massive environmental degradation and human rights violations is the rise of global inequality. Global law practitioners typically fail to appreciate that their role in facilitating a global political economy is also creating a world of increasing socioeconomic disparities between the very rich and the billions of poor. These inequalities are most evident in developing countries in the global south but they are also increasingly evident within the industrialized nations of the global north, the places where many corporate lawyers live (Piketty \& Zucman, 2013) ${ }^{7}$. And these inequalities have potentially huge ramifications in terms of fueling new forms of conflict, terrorism and violence both at home and overseas. So while the Occupy Movement of 2011 could not sustain itself for a variety of reasons (Gelder et al., 2011; Castells, 2012), criticisms of the prevailing global economic system reflected in this worldwide social movement have not abated or gone away. Ordinary people, the $99 \%$ of the world's population, continue to exist under declining socioeconomic conditions despite the supposed upward economic swing as measured in terms of multinational corporate profits and flourishing global law firms.

\footnotetext{
${ }^{6}$ While drilling for oil in Ecuador's Amazon rainforest region, Texaco—-which merged with Chevron in 2001—operated without concern for the environment or local residents. The company deliberately dumped billions of gallons of toxic wastewater into rivers and streams, spilled millions of gallons of crude oil, and abandoned hazardous waste in hundreds of unlined open-air pits littered throughout the region. The result is widespread devastation of the rainforest ecosystem and local indigenous communities, and one of the worst environmental disasters in history" (Amazon Watch, 2014).

${ }^{7}$ As President Obama has argued in light of the decline of middle-class in the United States, inequality is "the defining challenge of our time”. http://www.whitehouse.gov/the-press-office/2013/12/04/remarks-president-economic-mobility
} 
In the United States, issues of inequality and social justice have found new momentum within mainstream political conversations and are anticipated to feature in the lead up to the 2016 presidential elections. Against escalating calls for social justice, the number of the world's super-rich (individuals worth $\$ 50$ million or more) is growing rapidly and nowhere more so than in the United States which since mid-2013 has grown by 1.6 million. This gross disparity between the mega-rich and the very poor is creating new anxieties and concerns amongst analysts and tellingly also amongst the economic elite (Standing, 2011; Piketty, 2014). In the words of American Nick Hanauer, a self-proclaimed "proud and unapologetic capitalist", "I have a message for my fellow filthy rich, for all of us who live in our gated bubble worlds: Wake up people. It won't last. If we don't do something to fix the glaring inequities in this economy, the pitchforks are going to come for us” (Hanauer, 2014).

One consequence of growing social inequality is that many people are increasingly feeling distrustful of lawyers and legal systems that allow "big business" to flourish while ordinary people fall further and further down the socioeconomic scale and become increasingly desperate (Darian-Smith, 2013: pp. 378-383). In the United States, where lawyers are typically well-respected members of society, there has been a marked shift in public attitudes toward lawyers with the fallout of the economic recession. A 2013 Pew Research Center survey asked people what they thought about certain professions. It ranked lawyers behind 9 other professions (including business executives and artists) with 34\% of the respondents saying that lawyers contributed not very much or nothing at all to society (Pew Survey, 2013). We are facing, as a range of commentators are increasingly noting, a legitimacy crisis in law and legal institutions (Reese, 2013; Tamanaha, 2012). Widespread public distrust of lawyers and the legal institutions that they represent is growing, not decreasing.

In the United States, the long-term impact of the subprime mortgage crisis coupled with a gridlocked Congress unable to function without the approval of big business lobbyists are together creating a very low opinion of the legal profession. It is now readily apparent that law can be massaged and manipulated to justify torture, deny workers a living wage, gather unlimited data on one's personal life, and protect oil companies whose irresponsible practices cause billions of dollars of damages from liability beyond a nominal capping. Outside the United States, there is similar disillusionment in law which is widely viewed as an instrumental mechanism of power and a technical apparatus that serves special group interests. In short, there is a looming crisis in the legitimacy of western legality as the checks and balances envisioned by a system of representative governance are proving to be clearly inadequate (Falk et al., 2012; Boghosian, 2013). What we are now facing, argues Brian Tamanaha, is "the rule of some groups over others by and through the law, more so than a community united under a rule of law that furthers the common good" (Tamanaha, 2006: p. 225).

My point is that ignoring the "democratic deficit" and ordinary people's everyday concerns is to ignore the potentiality of the whole international financial system crumbling under conditions of chaos and fear (Porter, 2001). One only has to think of Greece whose desperate populations voted in a leftist leader Alexis Tsipras on January 25, 2015. Tsipras openly denounced the International Monetary Fund and the European Union as he told thousands of cheering supporters, "Greece leaves behinds catastrophic austerity, it leaves behind fear and authoritarianism, it leaves behind five years of humiliation and anguish"8. The degree to which the Tsipras-led government will be able to improve the plight of Greek citizens is not clear, but what is evident is the challenge it presents to the stability of the Euro Zone and global markets more generally. This unsettling of the Euro and world markets by pro-democracy movements was underscored by mass rallies erupting in London and throughout Europe on Sunday 15 February 2015 declaring support for the people of Greece. According to activists, "No one has the right to bypass the democratic decisions of a nation. European people are fighting to gether against deadly austerity and the further restriction of democracy. It is time to rise up and support the struggle for a Europe of solidarity and democracy" (see Butler, 2011; Knight, 2013) .

\section{Concluding Comments}

The narrative promoted by global law firms that their international legal transactions operate in a de-territorialized strata-sphere independent from the cultural and political realities of the places in which business is implemented is both misleading and inaccurate. Against this dominant narrative, I suggest that greater attention needs to be paid to a bottom-up understanding of global financial practices and the legal infrastructure that supports

\footnotetext{
${ }^{8}$ http://fortune.com/2015/01/25/greeces-radical-left-wins-snap-election-threatening-market-unrest/ (accessed 12 February 2015). ${ }^{9}$ http://criticallegalthinking.com/2015/02/14/rally-solidarity-greek-people-austerity-eu-blackmail-sunday-15-february-1-pm-trafalgar-square/ (accessed 16 February 2015).
} 
them as a counter-weight to the prevailing understanding of de-territorialized global corporatism. This is necessary because local contexts in which ordinary people live do matter. As sociolegal scholars are becoming increasingly aware, laws operate across a local/global continuum and to ignore the social, cultural and political dimensions that contextualize all legal transactions across a multi-scale continuum is shortsighted and may carry significant consequences (Darian-Smith, 2014; Zumbansen, 2012; Garcia, 2013).

Global law firms should be more explicitly attentive to real-world contexts for a number of reasons. The first reason is that local political cultures shape the ways global law firms operate and adapt their practices over time, and they do this by pushing back against global capitalism or at least modifying the terms of engagement. Instances of this pushback can be found in Greece's populist political movement, the World Social Forum, global occupy movements, indigenous resistance to Keystone XL Pipeline and so on. The second reason that global law firms should be attentive to real-world contexts is that elite commercial lawyers know better than most what Joseph Stiglitz, Nobel Prize-winner in Economics, has repeatedly argued, that "widening and deepening inequality is not driven by immutable economic laws, but by laws we have written ourselves" (Stiglitz, 2012). The tragedy is that laws that have aggressively transferred wealth from the bottom and middle to the top will ultimately undermine the legitimacy of the very legal frameworks needed for an efficient global economy to work (Stiglitz, 2012) ${ }^{10}$. In this context, it could be argued that global law firms in their functioning as the "lubricators of global capitalism" are actively_ even if not consciously—participating in their own eventual demise.

The third reason that global law firms should be attentive to real-world contexts, and arguably the most important reason of all, is that global law firms are participating in a global economic system that promotes social inequalities and so ultimately discredits the authority of law and legal institutions around the world (see Engels \& Engels, 2010). In serving the interests of "big business" and economic elite, global law firms are participating in the destabilization of both the global north and global south which is linked to massive environmental degradation, pollution, regional conflict and insecurity, and mass dislocations of people. Of course this litany of problems is not entirely the fault of global law firms, but it is hard to deny that their practitioners have enabled and empowered legal negotiations between a diverse range of investment financiers and multinational corporations involved in a wide variety of development, labor and extractive industries across national borders, regions and continents. And these industries have often exacerbated—if not caused—regional conflicts, civil wars, authoritarian regimes and so on (see Ferguson, 2006). Global law firms, as discussed above, are strategically positioned to take advantage of largely unregulated transnational market operations that enjoy immunity from public accountability and continue to lack internal regulatory controls (Howson, 2009; Harris, 2013). By facilitating in the de-legitimation of legal frameworks and regulatory processes, global law firms are helping to undermine national and global legal systems necessary to ensure the authority of legal practices and future stability of democratic institutions.

The world is moving at a fast pace, often in directions unforeseen and unplanned. Amongst deans and professors in law schools around the world, the case is being increasingly made that legal education should be reformed in order to better prepare future legal practitioners deal with the complex interrelated legal challenges of the 21 ${ }^{\text {st }}$ century (see Sturm, 2013; Flood, 2011; Arthurs, 2009, 2013; Empson, 2007). Some progressive law schools have actively supported new legal approaches that speak to law's role in both producing and mitigating global inequalities such as The Centre for Responsibilities, Rights and the Law at Sussex University, England. Other law schools, such as Jindal Global Law School (Haryana, India), McGill Faculty of Law (Montreal, Canada), and Kings College (London, UK) promote comparative law and legal pluralist approaches in order to better understand "urgent transnational legal problems of poverty, climate change, financial governance and postconflict justice" $"$.

One of the most significant legal challenges of the $21^{\text {st }}$ century, but one largely overlooked by law school educators, is the prevailing narrative that transnational corporate law operates in a de-territorialized global sphere far from the local contexts in which commercial and industrial operations come to ground and impact the lives of ordinary people. This narrative conveniently veils the ethical and material implications of global capitalism, and provides cover for global legal practitioners to not think about the long-term impacts of their work. Yet this blinkered perspective contributes indirectly to furthering social inequalities across the world and jeo-

\footnotetext{
${ }^{10}$ As argued by development economists, "Members of the middle class are more likely to play the positive political role in the provision of accountable government, e.g. in supporting the rule of law, property rights, and taxes to finance public goods such as education” (Birdsall, 2010: p. 10).

${ }^{11}$ http://www.kcl.ac.uk/prospectus/graduate/transnational-law
} 
pardizes the legitimacy of all legal institutions at whatever geopolitical scale. As argued in this article, the very future of our democratic aspirations and institutions may depend upon creating anew the middle classes and closing the gap between the rich and the poor. Global legal practitioners need to be educated that they too have a vested interest in this happening as much as the rest of the world's increasingly impoverished millions of people in the global south and the global north.

\section{References}

Amazon Watch (2014). http://amazonwatch.org/work/chevron

Angel, T. (2007). Your Challenge: Sustaining Partnership in the $21^{\text {st }}$ Century: The Global Law Firm Experience. In L. Empson (Ed.), Managing the Modern Law Firm (pp. 196-217). Oxford: Oxford University Press.

Arthurs, H. (2009). Law and Learning in an Era of Globalization. CLPE Research Paper No. 22/09.

Arthurs, H. (2013). The Future of Legal Education: Three Visions and a Prediction. Osgoode Hall Law School Research Paper Series No. 49/2013.

Berman, P. S. (2012). Global Legal Pluralism: A Jurisprudence of Law beyond Borders. Cambridge: Cambridge University Press. http://dx.doi.org/10.1017/CBO9781139028615

Birdsall, N. (2010). The (Indispensable) Middle Class in Developing Countries; or, the Rich and the Rest, Not the Poor and the Rest. CGD Working Paper 207. Washington DC: Center for Global Development.

Boghosian, H. (2013). Spying on Democracy: Government Surveillance, Corporate Power and Public Resistance. San Francisco: City Lights Publishers.

Butler, J. (2011). Fiscal Crisis, or the Neo-Liberal Assault on Democracy? Greek Left Review. https://greekleftreview.wordpress.com/2011/11/12/1718/

Castells, M. (2012). Networks of Outrage and Hope: Social Movements in the Internet Age. New York: Polity.

Darian-Smith, E. (2013). Laws and Societies in Global Contexts: Contemporary Approaches. Cambridge: Cambridge University Press.

Darian-Smith, E. (2014). “Locating a Global Perspective”. Symposium: Legal Scholarship and Globalization: Engagements with William Twining. Transnational Legal Theory, 4, 524-526.

Darrow, M. (2006). Between Light and Shadow: The World Bank, the International Monetary Fund and International Human Rights Law. Oxford: Hart.

Empson, L. (Ed.) (2007). Managing the Modern Law Firm. Oxford: Oxford University Press.

Engel, D. M., \& Engel, J. S. (2010). Tort, Custom, and Karma: Globalization and Legal Consciousness in Thailand. Palo Alto, CA: Stanford University Press.

Etherington, L., \& Lee, R. G. (2007). Ethical Codes and Cultural Context: Ensuring Legal Ethics in the Global Law Form. Indiana Journal of Global Legal Studies, 14, 95-118. http://dx.doi.org/10.2979/GLS.2007.14.1.95

Falk, R., Juergensmeyer, M., \& Popovski, V. (Eds.) (2012). Legality and Legitimacy in Global Affairs. Oxford: Oxford University Press.

Faulconbridge, J. R., Beaverstock, J. V., Muzio, D., \& Taymor, P. J. (2008). Global Law Firms: Globalization and Organizational Spaces of Cross-Border Legal Work. Northwestern Journal of International Law \& Business, 28, 455-488.

Ferguson, J. (2006). Global Shadows: Africa in the Neoliberal World. Durham, NC: Duke University Press. http://dx.doi.org/10.1215/9780822387640

Flood, J. (2007). Lawyers as Sanctifiers: The Role of Elite Law Firms in International Business Transactions. Indiana Journal of Global Legal Studies, 14, 35-66. http://dx.doi.org/10.2979/GLS.2007.14.1.35

Flood, J. (2011) Legal Education in the Global Context: Challenges from Globalization, Technology and Changes in the Government Regulation. Report for the Legal Services Board. University of Westminster School of Law, Research Paper No. 11-16.

Garcia, F. J. (2013). Global Justice and International Economic Law: Three Takes. Cambridge: Cambridge University Press. http://dx.doi.org/10.1017/CBO9781139410908

Gelder, S. V. (Ed.) (2011). This Changes Everything: Occupy Wall Street and the 99\% Movement. Oakland, CA: BerrettKoehler Publishers.

Ghazi, B. (2005). The IMF, the World Bank Group and the Question of Human Rights. Ardsley, NY: Transnational Publishers.

Griffiths, A. (2013). Reviewing Legal Pluralism. In R. Banakar, \& M. Travers (Eds.), An Introduction to Law and Social Theory (2nd ed., pp. 269-286). Oxford: Hart. 
Hanauer, N. (2014). The Pitchforks Are Coming...For Us Plutocrats. Politico Magazine. http://www.politico.com/magazine/story/2014/06/the-pitchforks-are-coming-for-us-plutocrats-108014.html\#.U9vZJk10zIU

Harris, M. (2013). Law Firms and Overcharging: The System Itself Is Rotten. http://www.forbes.com/sites/forbesleadershipforum/2013/04/03/law-firms-and-overcharging-the-system-itself-is-rotten/

Held, D. (2002). Culture and Political Community: National, Global, and Cosmopolitan. In S. Vertovec, \& R. Cohen (Eds.), Conceiving Cosmopolitanism: Theory, Context, Practice (pp. 48-58). Oxford: Oxford University Press.

Howson, N. C. (2009). When “Good” Corporate Governance Makes “Bad” (Financial) Firms: The Global Crisis and the Limits of Private Law. Michigan Law Review, First Impressions, 108, 44.

Klein, N. (2008). Shock Doctrine: The Rise of Disaster Capitalism. New York: Picador.

Klein, N. (2014). This Changes Everything: Capitalism vs. the Climate. New York: Simon \& Schuster.

Knight, D. M. (2013). The Desire to Blame Greece for the Eurocrisis Ensures That the Greek People Pay the Price, While the Elites Responsible Get Away Free. European Politics and Policy at LSE (9 January 2013) Blog Entry.

Le Goff, P. (2007). Global Law: A Legal Phenomenon Emerging from the Process of Globalization. Indiana Journal of Global Legal Studies, 14, 119-145. http://dx.doi.org/10.2979/GLS.2007.14.1.119

Lothian, T. (2014). Democracy, Law and Global Finance: An Example of Research Agenda for a New Practice of Law and Economics. The Center for Law and Economic Studies, Columbia University School of Law Working Paper Series.

Merry, S. E. (2008). International Law and Sociolegal Scholarship: Toward a Spatial Global Legal Pluralism. Special Issue: Law and Society Reconsidered. Studies in Law, Politics and Society, 41, 149-168. http://dx.doi.org/10.1016/S1059-4337(07)00006-3

Michaels, R. (2009). Global Legal Pluralism. Annual Review of Law and Social Science, 5, 243-262. http://dx.doi.org/10.1146/annurev.lawsocsci.4.110707.172311

Nixon, R. (2011). Slow Violence and the Environmentalism of the Poor. Cambridge, MA: Harvard University Press. http://dx.doi.org/10.4159/harvard.9780674061194

Pew Survey (2013). Public Esteem for Military Still High. http://www.pewforum.org/2013/07/11/public-esteem-for-military-still-high/

Piketty, T. (2014). Capital in the Twenty-First Century. New York: Belknap Press.

Piketty, T. and Zucman, G. (2013). Capital Is Back: Wealth-Income Ratios in Rich Countries 1700-2010. http://piketty.pse.ens.fr/files/PikettyZucman2013WP.pdf

Porter, T. (2001). The Democratic Deficit in the Institutional Arrangements for Regulating Global Finance. Global Governance, 7, 427-439.

Reese, F. (2013). Americans Are Distrustful of "Big Business": Is Change in the Air? http://www.mintpressnews.com/americans-are-distrustful-of-big-business-is-change-in-the-air/46054/

Greenwood, R. (2007). Your Ethics: Redefining Professionalism? The Impact of Management. In L. Empson (Ed.), Managing the Modern Law Firm (pp. 186-195). Oxford: Oxford University Press.

Sassen, S. (2008). Neither Global Nor National: Novel Assemblages of Territory, Authority and Rights. Ethics \& Global Politics, 1, 61-79.

Silver, C. (2007). Local Matters: Internationalizing Strategies for US Law Firms. Indiana Journal of Global Legal Studies, 14, 67-93. http://dx.doi.org/10.2979/GLS.2007.14.1.67

Sokol, D. D. (2007). Globalization of Law Firms: A Survey of the Literature and a Research Agenda for Further Study. Indiana Journal of Global Legal Studies, 14, 5-28. http://dx.doi.org/10.2979/GLS.2007.14.1.5

Standing, G. (2011). The Precariat: The New Dangerous Class. London: Bloomsbury Academic.

Stiglitz, J. (2012). The Price of Inequality: How Today's Divided Society Endangers Our Future. New York: W.W. Norton \& Company.

Sturm, S. (2013). Law Schools, Leadership, and Change. Harvard Law Review, 127.

Tamanaha, B. Z. (2012). Failing Law Schools (Chicago Series in Law and Society). Chicago: University of Chicago Press. http://dx.doi.org/10.7208/chicago/9780226923628.001.0001

Tamanaha, B. Z. (2006). Law as a Means to an Ends: Threat to the Rule of Law. Cambridge: Cambridge University Press. http://dx.doi.org/10.1017/CBO9780511511073

Tamanaha, B. Z., Sage, C., \& Woolcock, M. (Eds.) (2012). Legal Pluralism and Development. Cambridge: Cambridge University Press. http://dx.doi.org/10.1017/CBO9781139094597

Terry, L. S. (2008). The Legal World Is Flat: Globalization and Its Effect on Lawyers Practicing in Non-Global Law Firms. Northwestern Journal of International Law \& Business, 28, 527-559.

Twining, W. (2009). Globalization and Legal Scholarship (Vol. 4). Tilburg Law Lecture Series, Montesquieu Seminars. 
Zaretsky, S. (2013). Bow before the Global 100, the Top-Grossing Law Firms on the Planet. BigLaw. http://abovethelaw.com/2013/10/bow-before-the-global-100-the-top-grossing-law-firms-on-the-planet/2/

Zumbansen, P. (2012). Defining the Space of Transnational Law: Legal Theory, Global Governance and Legal Pluralism. In G. Handl, J. Zekoll, \& P. Zumbansen (Eds.), Beyond Territoriality: Transnational Legal Authority in an Age of Globalization (pp. 53-87). Leiden and Boston: Martinus Nijhoff Publishers. http://dx.doi.org/10.1163/9789004227095_005

Zumbansen, P. (2013). Law and Legal Pluralism: Hybridity in Transnational Governance. In P. Jurcys, P. F. Kjaer, \& R. Yatsunami (Eds.), Regulatory Hybridization in the Transnational Sphere (pp. 49-70). Leiden and Boston: Martinus Nijhoff Publishers. 